\title{
Relation of food intake to nutritional status of students in islamic boarding schools
}

\author{
Syarfaini ${ }^{1}$, Ulfah Humaidah ${ }^{2}$, Irviani Ibrahim ${ }^{3}$ \\ 1,2,3 Bagian Gizi Universitas Islam Negeri Alauddin
}

\begin{abstract}
Adolescence is a period of dramatic change in a person. This sudden increase in growth is accompanied by hormonal, cognitive and emotional changes. Teenagers really need more nutrients because of increased growth and physical development that is very drastic. This study aims to determine the relationship of food intake with the nutritional status of adolescent students of SMP Buq'atun Mubarakah Pondok Pesantren Darul Aman Makassar. This research method used quantitative analytic with cross sectional approach. Retrieval of food intake data used the food weighing method for 3 consecutive days. Determination of nutritional status was obtained from BMI/A parameters (body mass index/age). Statistical test results showed no relationship between energy intake, protein intake, vitamin A intake, iron, zinc and fat intake with the nutritional status of students, but we obtained a significant relationship between carbohydrate intake and nutritional status. In addition, we found no relationship between diarrheal infections and typhoid infections with nutritional status. We recommend that the pesantren can design a varied list of food menus for students to fulfill a balanced nutritional status
\end{abstract}

Keywords: food intake; infectious diseases; nutritional status

\begin{abstract}
ABSTRAK
Masa remaja merupakan masa perubahan yang dramatis dalam diri seseorang. Peningkatan pertumbuhan mendadak ini disertai dengan perubahan-perubahan hormonal, kognitif dan emosional. Remaja sangat membutuhkan zat gizi yang lebih banyak karena peningkatan pertumbuhan dan perkembangan fisik yang sangat drastis. Penelitian ini bertujuan untuk mengetahui hubungan asupan makanan dengan status gizi santri remaja SMP Buq'atun Mubarakah Pondok Pesantren Darul Aman Makassar. Metode penelitian ini menggunakan analitik kuantitatif dengan pendekatan cross sectional. Pengambilan data asupan makanan menggunakan metode food weighing selama 3 hari berturut-turut. Penentuan status gizi diperoleh dari parameter IMT/U (Indeks Massa tubuh/Umur). Hasil uji statistik menunjukan tidak ada hubungan asupan energi, asupan protein, asupan vitamin A, zat besi, zink dan asupan lemak dengan status gizi santri, namun kami memperoleh hubungan yang signifikan antara asupan karbohidrat dengan status giz. Selain itu, kami tidak menemukan hubungan penyakit infeksi diare maupun penyakit infeksi thypus dengan status gizi. Kami merekomendasikan agar pihak pesantren dapat merancang daftar menu makanan yang bervariasi untuk para santri agar terpenuhi status gizi yang seimbang.
\end{abstract}

Kata kunci: asupan makanan; penyakit infeksi; status gizi

\section{PENDAHULUAN}

Kualitas sumber daya manusia (SDM) adalah faktor utama yang diperlukan untuk melaksanakan berbagai program pambangunan nasional. Untuk meningkatkan kualitas SDM, maka perlu dilakukan upaya-upaya yang saling berkesinambungan. Berbagai macam faktor yang mempengaruhi kualitas SDM, faktor kesehatan dan gizi merupakan faktor yang memegang peranan penting, dikarenakan seseorang tidak akan mampu mengembangkan suatu kapasitasnya secara maksimal apabila orang tersebut tidak mempunyai status kesehatan gizi yang optimal

PBB menyatakan bahwa sekitar 800 
juta penduduk dunia menderita gizi kurang dan sebagian besarnya terjadi di negara berkembang. Berdasarkan data indonesia menduduki peringkat ke 5 dengan angka anak pendek terbesar di dunia yaitu 36\% dengan menyumbang $4,6 \%$ untuk dunia

Berdasarkan data Riset Kesehatan Dasar (Riskesdas) pada tahun 2007, secara nasional prevalensi kurus anak usia sekolah umur 6-14 tahun adalah 24,2\%. Sedangkan prevalensi BB lebih 15,9\%. Selanjutnya pada tahun 2010, secara nasional prevalensi kependekan pada umur 13-15 tahun adalah $35,2 \%$. Sedangkan prevalensi kekurusan adalah 10,1\% dan prevalensi kegemukan adalah 2,5\%. Sedangkan pada tahun 2013, prevalensi pendek pada remaja kisaran umur 13-15 tahun ialah 35,1\%. Selanjutnya prevalensi kurus adalah 11,1\%. Selanjutnya prevalensi gemuk adalah 10,8\%. Perubahan terutama pada prevalensi kependekan yaitu 0,1\% dari tahun 2010 dan 2013. Selanjutnya prevalensi kekurusan menurun yaitu 14,1\% dari tahun 2007 dan 2010 dan naik 1\% pada tahun 2013. Sedangkan prevalensi kegemukan menurun $13,4 \%$ dari tahun 2007 dan 2010 dan naik sebesar 8,3\% tahun 2013. Propinsi Sulawesi selatan tahun 2010 termasuk dalam 12 popinsi dengan prevalensi anak kurus yaitu $10,1 \%$ dan padat tahun 2013 termasuk dalam 17 propinsi dengan prevalensi anak sangat kurus.

Santri yang ada di pondok pesantren berada pada usia remaja. Dimana, usia remaja merupakan usia yang rentan terhadap gizi yang dikarenakan berbagai sebab. Remaja sangat membutuhkan zat gizi yang lebih banyak karena peningkatan pertumbuhan dan perkembangan fisik yang sangat drastis. Perubahan gaya hidup maupun kebiasaan makan terhadap remaja mampu mempengaruhi asupan makanan serta kebutuhan zat gizi remaja. Remaja sangat aktif dalam berbagai macam bidang olahraga. Hal-hal tersebut yang menyebabkan remaja membutuhkan energi dan zat gizi lain yang lebih banyak. Dengan demikian para remaja harus memperoleh asupan makanan yang sesuai dengan kebutuhannya untuk mendukung proses metabolisme tubuh (Almatsier, 2010).

Berdasarkan uraian diatas, dengan melihat cukup besarnya permasalahan mengenai status gizi serta kaitannya dengan asupan makanan terhadap status gizi remaja, mendorong peneliti untuk meneliti mengenai hubungan asupan makanan dengan status gizi santri remaja SMP buq'atun mubarakah pondok pesantren darul aman makassar.

\section{METODE PENELITIAN}

Jenis penelitian ini menggunakan penelitian analitik kuantitatif dengan pendekatan Cross Sectional Study yaitu penelitian yang menekankan pada waktu 
pengukuran atau observasi data dalam satu kali pada suatu waktu yang dilakukan pada variabel terikat dan variabel bebas. Pendekatan ini digunakan untuk melihat hubungan antara variabel satu dengan variabel lainnya (Nikmah, 2015). Penelitian ini dilakukan di SMP Buq'atun Mubarakah Pondok Pesantren Darul Aman Makassar yang dilaksanakan pada bulan Juli-September 2018. Populasi dalam penelitian ini adalah semua santri remaja SMP Buq'atun $\mathrm{Mu}-$ barakah Pondok Pesantren Darul Aman Makassar dengan jumlah populasi adalah 498 santri yang terbagi dalam 3 tingkatan/ kelas.

Sampel dalam penelitian ini menggunakan proportionate stratified ran- homogen yang terdiri dari atas kelompok yang homogen atau berstrata secara proporsi yang sama serta berdasarkan kriteria inklusi dan ekslusi. Pengambilan sampel dilakukan secara simple random sampling dengan cara menggunakan teknik acak sederhana yaitu dengan melakukan undian dan jumlah sampel sebanyak 221 responden (Nikmah, 2015).

\section{HASIL PENELITIAN}

Berdasarkan tabel 1, menunjukkan dari 221 responden di SMP Buq'atun mubarakah pondok pesantren darul aman makassar distribusi pendidikan/kelas responden paling banyak adalah kelas 1 yaitu 97 responden $(43.9 \%)$ dan paling sedikit yaitu

Tabel 1. Karakteristik Responden

\begin{tabular}{cccc}
\hline No & Karakteristik responden & Jumlah (n) & Presentase (\%) \\
\hline \multirow{2}{*}{1} & Pendidikan/kelas & 97 & 43.9 \\
& Kelas 1 & 66 & 29.9 \\
& Kelas 2 & 66.2 & 26.2 \\
2 & Kelas 3 & 58 & 57.9 \\
& Jenis kelamin & & 42.1 \\
3 & Laki-laki & 128 & 97.7 \\
& Perempuan & 93 & 2.3 \\
\hline
\end{tabular}

Sumber: Data Primer, 2018

dom sampling dikarenakan anggota populasi terdiri dari 3 tingkatan pendidikan. Proportionate stratified random sampling adalah suatu cara pengambilan sampel yang digunakan bila anggota populasinya tidak pendidikan/kelas 3 sebanyak 58 responden (26.2\%). Berdasarkan jenis kelamin lakilaki sebanyak 128 responden (57.9\%) sedangkan perempuan sebanyak 93 responden $(42.1 \%)$. Berdasarkan umur 12-14 tahun 
sebanyak 216 responden (97.7\%) sedangkan umur 15-16 tahun sebanyak 5 responden (2.3\%) (Data primer, 2018).

Berdasarkan tabel 2, menunjukkan dari 221 responden di SMP Buq'atun mubarakah pondok pesantren darul aman makassar jumlah status gizi yang paling ban- cukup sebanyak 60 responden $(27.1 \%) \mathrm{ku}-$ rang sebanyak 161 responden $(72.9 \%)$, asupan protein cukup sebanyak 49 responden $(22.2 \%)$ kurang sebanyak 172 responden (77.8\%), asupan lemak cukup sebanyak 11 responden $(5.0 \%)$ kurang sebanyak 210 responden (95.0\%), asupan vitamin A cukup

Tabel 2. Distribusi Responden Berdasarkan Status Gizi IMT/U, Asupan Makanan dan Penyakit Infeksi

\begin{tabular}{|c|c|c|c|}
\hline Variabel & Kategori & Jumlah & Persentase \\
\hline \multirow{4}{*}{ Status Gizi } & Normal & 122 & 55.2 \\
\hline & Kurus & 47 & 21.2 \\
\hline & Gemuk & 22 & 10 \\
\hline & Obesitas & 30 & 13.6 \\
\hline \multirow{2}{*}{ Asupan energ } & Cukup & 27 & 11.8 \\
\hline & Kurang & 194 & 88.2 \\
\hline \multirow{2}{*}{ Asupan karbohidrat } & Cukup & 60 & 27.1 \\
\hline & Kurang & 161 & 72.9 \\
\hline \multirow{2}{*}{ Asupan protein } & Cukup & 49 & 22.2 \\
\hline & Kurang & 172 & 77.8 \\
\hline \multirow{2}{*}{ Asupan lemak } & Cukup & 11 & 5 \\
\hline & Kurang & 210 & 95 \\
\hline \multirow{2}{*}{ Asupan vit. A } & Cukup & 1 & 0.5 \\
\hline & Kurang & 220 & 99.5 \\
\hline \multirow{2}{*}{ Asupan vit. C } & Cukup & 0 & 0 \\
\hline & Kurang & 221 & 100 \\
\hline \multirow{2}{*}{ Asupan zat besi } & Cukup & 10 & 4.5 \\
\hline & Kurang & 211 & 95.5 \\
\hline \multirow{2}{*}{ Asupan kalsium } & Cukup & 0 & 0 \\
\hline & Kurang & 221 & 100 \\
\hline \multirow{2}{*}{ Asupan zink } & Cukup & 2 & 0.9 \\
\hline & Kurang & 219 & 99.1 \\
\hline \multirow{2}{*}{ Penyakit ISPA } & Ada & 7 & 3.2 \\
\hline & Tidak ada & 214 & 96.8 \\
\hline \multirow{2}{*}{ Penyakit diare } & Ada & 8 & 3.6 \\
\hline & Tidak ada & 213 & 96.4 \\
\hline \multirow{2}{*}{ Penyakit thypus } & Ada & 16 & 7.2 \\
\hline & Tidak ada & 205 & 92.8 \\
\hline
\end{tabular}

Sumber: Data Primer, 2018

yak adalah normal sebanyak 122 responden $(55.2 \%)$ dan paling sedikit yaitu gemuk sebanyak 22 responden (10.0\%). Berdasarkan jumlah asupan energi cukup sebanyak 27 responden (11.8\%) kurang sebanyak 194 responden (88.2\%), asupan karbohidrat sebanyak 1 responden $(0.5 \%)$ kurang sebanyak 220 responden (99.5\%), asupan vitamin $\mathrm{C}$ kurang sebanyak 221 responden (100.0\%), asupan zat besi cukup sebanyak 10 responden $(4.5 \%)$ kurang sebanyak 211 responden (95.5\%), asupan kalsium kurang 
sebanyak 221 responden (100.0\%), asupan zink cukup sebanyak 2 responden $(0.9 \%)$ kurang sebanyak 219 responden (99.1\%).

Sedangkan berdasarkan jumlah penyakit infeksi ISPA ada sebanyak 7 responden (3.2\%) tidak ada sebanyak 214 responden $(96.8 \%)$, penyakit diare ada sebanyak 8 responden (3.6\%) tidak ada sebanyak 213 responden $(96.4 \%)$ serta penyakit thypus ada sebanyak 16 responden (7.2\%) tidak ada sebanyak 205 responden $(92.8 \%)$

Berdasarkan tabel 3, analisis hubungan antara asupan energi $(\mathrm{p}=0.126)$, protein $(p=0.337)$, lemak $(p=0.197)$, vitamin $A$ $(p=0.367)$, zat besi $(p=0.107)$, zink $(\mathrm{p}=0.115)$ terhadap status gizi bahwa tidak memiliki hubungan yang bermakna. Sedangkan antara asupan karbohidrat dengan status gizi memiliki hubungan yang bermakna dimana nilai $\mathrm{p}=0.036$. Berdasarkan penyakit infeksi ISPA $(p=0.504)$, diare $(p=0.305)$, dan thypus $(p=0.339)$ terhadap status gizi bahwa tidak memiliki hubungan yang bermakna antara penyakit infeksi dengan status gizi.

\section{PEMBAHASAN}

Asupan energi memiliki peran penting dalam penentuan status gizi sebab energi dibutuhkan dalam metabolisme basal, mengembalikan sel, jaringan atau sistem setelah adanya penyakit atau kerusakan. Kemudian setelah energi terpenuhi energi yang masih tersisa dapat digunakan untuk pertumbuhan (Arifiyanti ,2016).

Dari hasil uji statistik diperoleh $\mathrm{p}=$ 0.201 maka Ha ditolak yang artinya tidak ada hubungan asupan energi dengan status gizi remaja berdasarkan Indeks Massa Tubuh menurut umur (IMT/U). Hal ini sejalan dengan penelitian (Sofiatun 2017) yang menunjukan bahwa tidak ada hubungan asupan energi dengan status gizi, hal ini dapat diliat dari responden pada kelompok yang mempunyai asupan energi kurang, sebagian besar mempunyai status gizi normal. Hal ini juga dikarenakan asupan makanan yang dikonsumsi tidak memenuhi berdasarkan angka kecukupan gizi masing-masing individu.

Peranan utama karbohidrat didalam tubuh adalah menyediakan glukosa bagi sel -sel tubuh yang kemudian diubah menjadi energi. Menurut (Mokoginta dkk, 2016) energi berasal dari karbohidrat, maka makanan sumber karbohidrat digolongkan sebagai makanan pokok.

Dari hasil statistik diperoleh $\mathrm{p}=$ 0.036 maka Ho diterima yang artinya ada hubungan asupan karbohidrat dengan status gizi remaja berdasarkan Indeks Massa Tubuh menurut umur (IMT/U). Penelitian ini sejalan dengan penelitian yang dilakukan oleh Muchlisa (2012) dalam Rahmawati (2017), yang mengatakan adanya hubungan antara asupan karbohidrat 
dengan status gizi remaja. Jumlah remaja dengan asupan karbohidrat yang cukup lebih banyak yang status gizinya tergolong normal.

Status gizi secara langsung dipengaruhi oleh asupan makanan, salah satunya adalah protein. Protein adalah bagian dari sel hidup dan merupakan bagian ada hubungan asupan protein dengan status gizi remaja berdasarkan Indeks Massa Tubuh menurut umur (IMT/U). Selain itu, penelitian ini sejalan dengan penelitian yang dilakukan oleh Rahmawati (2017) yang mengatakan bahwa antara asupan protein dengan status gizi tidak memiliki hubungan yang signifikan.

Tabel 3. Analisis Hubungan Asupan Makanan, Penyakit Infeksi dengan Status Gizi

\begin{tabular}{|c|c|c|c|c|c|c|c|c|}
\hline \multirow{4}{*}{\multicolumn{2}{|c|}{ Variabel independen }} & \multirow{2}{*}{\multicolumn{4}{|c|}{$\begin{array}{c}\text { Variabel dependen } \\
\text { Status Gizi }\end{array}$}} & \multirow{2}{*}{\multicolumn{2}{|c|}{ Total }} & \multirow{4}{*}{$p$ value } \\
\hline & & & & & & & & \\
\hline & & \multicolumn{2}{|c|}{ Normal } & \multicolumn{2}{|c|}{ Tidak Normal } & \multirow{2}{*}{$\mathrm{N}$} & \multirow{2}{*}{$\%$} & \\
\hline & & $\mathrm{n}$ & $\%$ & $\mathrm{~N}$ & $\%$ & & & \\
\hline \multirow{2}{*}{ Asupan energ } & Cukup & 19 & 70 & 8 & 30 & 27 & 100 & \multirow{2}{*}{0.126} \\
\hline & Kurang & 103 & 53 & 91 & 47 & 194 & 100 & \\
\hline \multirow{2}{*}{$\begin{array}{l}\text { Asupan kar- } \\
\text { bohidrat }\end{array}$} & Cukup & 40 & 66.7 & 20 & 33.3 & 60 & 100 & \multirow{2}{*}{0.036} \\
\hline & Kurang & 82 & 51 & 79 & 49 & 161 & 100 & \\
\hline \multirow{2}{*}{$\begin{array}{l}\text { Asupan pro- } \\
\text { tein }\end{array}$} & Cukup & 30 & 61.2 & 19 & 38.8 & 49 & 100 & \multirow{2}{*}{0.337} \\
\hline & Kurang & 92 & 53.4 & 80 & 46.6 & 172 & 100 & \\
\hline \multirow{2}{*}{ Asupan lemak } & Cukup & 4 & 36.3 & 7 & 63.7 & 11 & 100 & \multirow{2}{*}{0.197} \\
\hline & Kurang & 118 & 56.1 & 92 & 43.9 & 210 & 100 & \\
\hline \multirow{2}{*}{ Asupan vit. A } & Cukup & 1 & 100 & 0 & 0 & 1 & 100 & \multirow{2}{*}{0.367} \\
\hline & Kurang & 121 & 55 & 99 & 45 & 220 & 100 & \\
\hline \multirow{2}{*}{ Asupan vit. C } & Cukup & 0 & 0 & 0 & 0 & 0 & 0 & \multirow{2}{*}{ - } \\
\hline & Kurang & 122 & 55.2 & 99 & 44.8 & 221 & 100 & \\
\hline \multirow{2}{*}{$\begin{array}{l}\text { Asupan zat } \\
\text { besi }\end{array}$} & Cukup & 8 & 80 & 2 & 20 & 10 & 100 & \multirow{2}{*}{0.107} \\
\hline & Kurang & 114 & 54 & 97 & 46 & 211 & 100 & \\
\hline \multirow{2}{*}{$\begin{array}{l}\text { Asupan } \\
\text { kalsium }\end{array}$} & Cukup & 0 & 0 & 0 & 0 & 0 & 0 & \multirow{2}{*}{ - } \\
\hline & Kurang & 122 & 55.2 & 99 & 44.8 & 221 & 100 & \\
\hline \multirow{2}{*}{ Asupan zink } & Cukup & 0 & 0 & 2 & 100 & 2 & 100 & \multirow{2}{*}{0.115} \\
\hline & Kurang & 122 & 55.8 & 97 & 44.2 & 219 & 100 & \\
\hline \multirow{2}{*}{ Penyakit ISPA } & Ada & 3 & 42.9 & 4 & 57.1 & 7 & 100 & \multirow{2}{*}{0.504} \\
\hline & Tidak ada & 119 & 55.7 & 95 & 44.3 & 214 & 100 & \\
\hline \multirow{2}{*}{ Penyakit diare } & Ada & 3 & 37.5 & 5 & 62.5 & 8 & 100 & \multirow{2}{*}{0.305} \\
\hline & Tidak ada & 119 & 55.9 & 94 & 44.1 & 213 & 100 & \\
\hline \multirow{2}{*}{$\begin{array}{c}\text { Penyakit } \\
\text { thypus }\end{array}$} & Ada & 7 & 43.8 & 9 & 56.2 & 16 & 100 & 0330 \\
\hline & Tidak ada & 115 & 56 & 90 & 44 & 205 & 100 & 0.359 \\
\hline
\end{tabular}

Sumber: Data Primer, 2018

terbesar sesudah air. Semua enzim, berbagai hormone, pengangkut zat-zat gizi dan darah merupakan protein (Almatsier, 2010).

Dari hasil uji statistik diperoleh $\mathrm{p}=$ 0.337 maka Ha ditolak yang artinya tidak
Lemak merupakan zat makanan penyumbang energi terbesar dibandingkan zat gizi lainnya yaitu 1 gram lemak akan menyumbang 9 kkal energi. Asupan lemak merupakan rata-rata jumlah (gram) lemak 
yang dikonsumsi dalam sehari (Almatsier, 2010).

Dari hasil uji statistik diperoleh $\mathrm{p}=$ 0.367 maka Ha ditolak yang artinya tidak ada hubungan asupan vitamin A dengan status gizi remaja berdasarkan Indeks Massa Tubuh menurut umur (IMT/U). Menurut Jannah (2014) bahwa idak ada hubungan antara asupan vitamin A dengan status gizi. Hal ini dikarenakan vitamin A berkaitan dengan metabolisme zat gizi makro. Secara teori vitamin A ini tidak secara langsung berkaitan dengan pertumbuhan tulang.

Pada difisiensi vitamin A terjadi hambatan pertumbuhan karena adanya hambatan sintesa protein. Gejala ini tampak pada remaja yang sedang ada dalam periode pertumbuhan yang pesat. Sintesa protein memerlukan vitamin A sehingga difisiensi vitamin ini terjadi hambatan sintesa protein yang pada gilirannya penghambat pertumbuhan (Mann dkk, 2001).

Dari hasil uji statistik diperoleh $\mathrm{p}=$ 0.367 maka Ha ditolak yang artinya tidak ada hubungan asupan vitamin A dengan status gizi remaja berdasarkan Indeks Massa Tubuh menurut umur (IMT/U). Selain itu, Jannah (2014) menyatakan bahwa vitamin A bukan faktor risiko terhadap status gizi.

Hubungan asupan vitamin $\mathrm{C}$ dengan status gizi santri remaja SMP Buq'atun mubarakah pondok pesantren darul aman makassar

Vitamin $\mathrm{C}$ adalah mikronutrient yang dibutuhkan oleh tubuh manusia terutama untuk pengaturan fungsi-fungsi dalam tubuh. Vitamin $\mathrm{C}$ ialah suatu molekul organic yang sangat diperlukan oleh tubuh untuk proses metabolisme dan pertumbuhan yang normal (Garrow, 2014).

Dari hasil penelitian yang didapatkan asupan vitamin $\mathrm{C}$ pada responden memiliki frekuensi kurang yaitu sebanyak 100\%. Kurangnya asupan vitamin $\mathrm{C}$ pada santri dikarenakan santri hanya mendapatkan asupan vitamin $\mathrm{C}$ dari sayur-sayuran dan buah-buahan dalam jumlah yang sedikit, tentunya asupan yang didapatkan kurang.

Zat besi merupakan mikroelemen yang esensial bagi tubuh. Zat ini terutama diperlukan dalam hemopoboesis (pembentukan darah) yaitu sintesis hemoglobin $(\mathrm{Hb})$. Hemoglobin yaitu oksigen yang mengantarkan eritrosit berfungsi penting bagi tubuh (Amanda, 2014).

Dari hasil uji statistik diperoleh $\mathrm{p}=$ 0.107 maka Ha ditolak yang artinya tidak ada hubungan asupan zat besi dengan status gizi remaja berdasarkan Indeks Massa Tubuh menurut umur (IMT/U). Penelitian ini sejalan dengan penelitian Putri (2016) yang mengatakan bahwa antara asupan zat besi dengan status gizi tidak memiliki hubungan yang signifikan.Pada penelitian ini santri memperoleh asupan zat besi yang 
cukup, tidak menjamin akan mempunyai status gizi yang normal karena seseorang dalam menentukan status gizi yang normal selain ditentukan oleh asupan zat besi juga dipengaruhi oleh penyakit infeksi yang mungkin diderita oleh santri.

Kalsium adalah mineral yang sangat penting bagi manusia antara lain bagi metabolisme tubuh, penghubung antar syaraf, kerja jantung dan pergerakan otot. Kecukupan asupan kalsium sangat penting untuk mencapai massa tulang puncak optimal. Asupan kalsium biasanya diperoleh dari susu, keju, ikan, daging, telur, kacangkacangan dan sayuran (Almatsier, 2001).

Dari hasil penelitian terhadap 221 terhadap, tidak adasantri yang memiliki asupan kalsium yang cukup sehingga dari 221 santri hanya memiliki asupan kurang. Hal ini menunjukan bahwa jumlah asupan kalsium pada SMP buq'atun mubarakah pondok pesantren darul aman makassar memiliki asupan kalsium kurang semua. Hal ini dikarenakan asupan kalsium kurang semua. Hal ini dikarenakan asupan makanan yang dikonsumsi tidak memenuhi berdasarkan angka kecukupan gizi masingmasing individu.

Zink merupakan salah satu mikronutrient yang berperan sangat penting pada pertumbuhan manusia karena memiliki struktur serta peran dibeberapa sistem enzim yang terlibat dalam pembentukan fisik, imunologi dan fungsi reproduksi (Sulistianingtias, 2017).

Dari hasil statistik diperoleh $\mathrm{p}=0.115$ maka Ha ditolak yang artinya tidak ada hubungan asupan zink dengan status gizi remaja berdasarkan Indeks Massa Tubuh menurut umur (IMT/U). Pada penelitian ini santri memperoleh asupan zink yang cukup, tidak menjamin akan mempunyai status gizi yang normal karena seseorang dalam menentukan status gizi yang normal selain ditentukan oleh asupan zink juga dipengaruhi oleh penyediaan makanan yang kurang sehingga asupannya kurang.

Penyakit infeksi merupakan salah satu penyakit yang sering terjadi pada anak-anak dimana salah satu penyebab infeksi adalah keadaan status gizi anak yang kurang yang secara langsung dipengaruhi oleh kurangnya pengetahuan tentang makanan yang bergizi. Kecukupan gizi yang baik pada anak akan meningkatkan daya tahan terhadap penyakit terutama penyakit infeksi (Putri dkk, 2016).

Dalam penelitian ini penyakit infeksi yang menjadi variabel penelitian adalah penyakit ISPA, diare dan thypus (dalam kurun waktu 2 minggu terakhir). Hasil penelitian menunjukan bahwa tidak ada hubungan $(p>0.05)$ antara penyakit infeksi dengan status gizi pada santri remaja SMP buq'atun mubarakah pondok pesantren darul aman makassar dengan nilai $\mathrm{p}$ masing- 
masing diperoleh untuk ISPA adalah $(p=0.504)$, diare $(p=0.305)$ dan thypus dengan nilai $(p=0.339)$. Hal ini sejalan dengan penelitian Erna (2015) bahwa tidak ada hubungan yang bermakna antara penyakit infeksi (ISPA,diare dan thypus) dengan status gizi pada balita di kelurahan kalibaru, Depok.

\section{KESIMPULAN}

Berdasarkan hasil penelitian yang telah dilakukan di SMP buq'atun mubarakah pondok pesantren darul aman makassar maka dapat disimpulkan bahwa: (1) Tidak ada hubungan antara asupan zat gizi makro (energi, protein dan lemak) dan terdapat hubungan antara asupan karbohidrat dengan status gizi IMT/U santri di SMP Buq'atun Mubarakah Pondok Pesantren Darul Aman Makassar. (2)Tidak ada hubungan antara asupan zat gizi mikro (vitamin $\mathrm{A}$, vitamin $\mathrm{C}$, zatbesi, kalsium, dan zink) dengan status gizi IMT/U santri di SMP Buq'atun Mubarakah Pondok Pesantren Darul Aman Makassar. (3)Tidak ada hubungan antara penyakit infeksi (ISPA, diare dan thypus) dengan status gizi IMT/U santri di SMP Buq'atun Mubarakah Pondok Pesantren Darul Aman Makassar.

\section{SARAN}

Adapun yang menjadi saran penelitian setelah melakukan penelitian ini yaitu: (1) Para santri membiasakan diri untuk hidup bersih dan sehat serta memperhatikan makanannya. (2) Perlu dibuatnya daftar menu makanan yang bervariasi untuk para santri supaya santri tidak merasa bosan dengan makanan yang disajikan. (3) Bagi peneliti selanjutnya, maka perlu lebih lanjut penelitian mengenai hubungan asupan makanan dengan status gizi dengan melihat variabel lain yang mempengaruhi status gizi seperti aktivitas fisik dan lainlain.

\section{DAFTAR PUSTAKA}

Almatsier, S. (2001). Prinsip Dasar Ilmu Gizi. Jakarta: PT. Gramedia Pustaka Utama.

Amanda, A. (2014). Hubungan Asupan Zat Gizi (Energi, Protein, Besi dan Seng), Stunting dan Stimulasi Psikososial dengan Status Motorik Anak Usia 3-6 Tahun di PAUD Wilayah Binaan Pusksesmas Kecamatan Kebayoran Lama. Skripsi: Jakarta: Fakultas Kedokteran dan Ilmu Kesehatan, Universitas Islam Negeri Syarif Hidatullah.

Arifiyanti, D. (2016). Hubungan Asupan Energi dan Lemak dengan Status Gizi Pada Remaja Putri Pondok Pesantren Ta'mirul Islam Surakarta. Jurnal: Fakultas Ilmu Kesehatan, Universitas Muhammadiyah Surakarta.

Erna M. (2015). Hubungan Karakteristik Santri dan Kebiasaan Mencuci Tangan dengan Kejadian Kecacingan di Pondok Pesantren Kabupaten Blitar: Jurnal: Universitas Muhammadiyah 
Surabaya, Vol. 8 No 1 hal 14-15.

Garrow J, dkk. (2014). Gizi dan Dietetika.

Edisi 2. Jakarta: EGC.

Jannah R. (2014). Pengaruh Pemberian Suplemen Vitamin terhadap Perubahn Status Gizi Balita Bawah Garis Merah (BGM) di Wilayah Kerja Puskesmas Kambat Utara Kabupaten Hulu Sungai Tengah. Skripsi: Banjar Baru: Sekolah Tinggi Ilmu Kesehatan.

Mann J, dkk. (2001). Buku Ajar Ilmu Gizi. Jakarta: EGC.

Mokoginta F, dkk. (2016). Gambaran Pola Asupan Makanan pada Remaja di Kabupaten Bolaang Mongondow Utara. Manado: Jurnal: E-Biomedik, Vol 4 No. 2.

Nikmah, M.(2015). Hubungan Tingkat Stress dengan Gejala Gangguan Pencernaan pada Santriwati Pondok Pesantren Sirojul Mukhlasin II Payaman Magelang. Skripsi: Jakarta: Fakultas Kedokteran dan Ilmu Kesehatan, Universitas Islam Negeri Syarif Hidayatullah.
Putri, N. (2016). Perbedaan Tingkat Konsumsi Protein, Vitamin $\mathrm{C}$ dan Zat Besi pada Remaja Putri di Panti Asupan Ikhlasul Amal 1 dan Pondok Pesantren Al-Anwar. Semarang: Skripsi: Fakultas Ilmu Keperawatan dan Kesehatan, Universitas Muhammadiyah.

Rahmawati, T. (2017). Hubungan Asupan Zat Gizi dengan Status Gizi Mahasiswa Gizi Semester 3 Stikes PKU muhammadiyah. Surakarta: Jurnal: Fakultas Kedokteran Universitas $\mathrm{Mu}$ hammadiyah, Vol 14 No. 2.

Sulistianingtias, E.(2017). Hubungan antara Asupan Zink dengan Kejadian Stunting pada Remaja di Sukoharjo Jawa Tengah. Surakarta: Jurnal: Fakultas Kedokteran, Universitas Muhammadiyah.

Sofiatun, A. (2017). Analisis Sistem Penyelenggaraan Makanan dan Hubungan Asupan Energi dan Zat Gizi Makro dengan Status Gizi pada Santri Remaja di Pondok Pesantrenn Daarul Rahman. Jurnal: Jakarta Barat: Fakultas Ilmu Kesehatan, Universitas Esa Unggul. 